commission. It says much for Makarov's original design that the Stalin-class ships incorporated many features of the Yermak. Indeed, the whole record of the Yermak is a remarkable tribute to the foresight of Makarov himself, to the ability of her designers, the skill of those who manned her, and last, but by no means least, to the British workmanship which went into her construction.

\title{
A NEW GENERAL ACCOUNT OF SVALBARD
}

[Review of Landet med de kalde kyster by Helge Ingstad. Oslo, Gyldendal Norsk Forlag, 1948. 422 p., illus., maps, $24 \mathrm{~cm}$. Price 32 N. Kr.]

Apart from Odd Arnesen's short account entitled Svalbardboken (Oslo, 1935) this is the first general work devoted solely to Svalbard since R. N. Rudmose Brown's Spitsbergen (London, 1920). It is tempting to compare the accounts of Ingstad and Rudmose Brown, despite the fact that there is a span of 28 years between the dates of publication. Both authors have an extensive knowledge of the archipelago, and also of other polar regions, and both wrote for a wide public. Ingstad has travelled widely in the Canadian Arctic and was Norwegian Sysselmann in East Greenland from 1932 to 1933, and in Svalbard from 1933 to 1935 , and for a short time again in 1947. Rudmose Brown, writing at the time when the sovereignty of Svalbard was under discussion, was apt to stress the importance of British explorers and British mining interests: Ingstad writing for a Norwegian public, proud of Norwegian prowess in Svalbard, is intent on emphasizing exploration, trapping and mining activity carried on by Norwegians.

Ingstad's book is divided into two main sections: the first deals with history, exploration, mining, physical features, flora and fauna; the second deals with the author's personal experiences as Sysselmann. The second is complementary to the first and the fact that this unusual combination of careful description together with personal reminiscence succeeds is a tribute to the skill of the author.

The first chapter supports the still disputed theory that Svalbard was discovered by Norwegian Vikings. Ingstad's arguments are largely based on Nansen's views although he also quotes later authorities. The title of the book itself is a translation into modern Norwegian of the Old Norse name Svalbard, "the land with the cold coasts". Most people would agree that in all probability the Vikings did visit the islands, but Ingstad fails to mention that there is still no sound proof that they did so.

The chapter on geology, geography, and the surrounding waters is very short. The geological account especially is slight, but the part dealing with hydrography and particularly ice conditions is useful. There are four chapters on animal life, one of which deals with the Polar Bear. It is in these chapters that Ingstad is thoroughly at home; he is an experienced trapper and has much of importance to say concerning conservation of stock. For this reason his chapters on the Russian and Norwegian trappers are of especial value. $\mathrm{He}$ also emphasizes the importance of the sealing and fishing in Svalbard waters. 
There are excellent chapters on the history and present state of coal-mining and a good summary of Svalbard's political history, with an interesting note on events in Svalbard between 1940 and 1945.

On exploration there are two chapters, one covering discovery and whaling up to about 1800 , the other covering later scientific work. The second is largely a summary of activity after 1800 and there is regrettably little information about expeditions after 1900 with the exception of Norwegian work. G. Binney and A. R. Glen are mentioned in passing, but the long series of Oxford and Cambridge expeditions between the two world wars receive little notice. Some expeditions are omitted in the general chapters on exploration but are mentioned later in the book. Thus a short account of the misfortunes of the Schröder-Stranz expedition, 1912-13, appears in a section dealing with the author's own visit to the Sorgfjorden area.

This haphazard manner of handling the material is the main weakness of the book, especially as no index is provided. It is to be hoped that this omission will be rectified in the next edition, as it cannot fail to enhance the usefulness of the book.

The second section is similar in style to Ingstad's other books, such as $\phi$ st for den store bre (Oslo, 1935), well-written with plenty of interesting detail. Ingstad travelled widely in Spitsbergen and used his own dog team, brought from East Greenland in 1933. On several occasions he made journeys up into the inland areas of Vestspitsbergen and travelled over Ny Friesland, visiting isolated trappers and Russian mines. The book ends with an account of his last visit in 1947; he describes the effects of the war, especially the damage caused by the German naval attack on Longyearbyen in 1944. There are two excellent maps and a useful and up-to-date list of references; furthermore there is a fine selection of illustrations.

Last year Norway celebrated its twenty-fifth year of sovereignty in Svalbard. Although this book appeared two years earlier, it was well-timed. Notwithstanding certain inconsistencies, it is an eminently readable account of Svalbard to-day, with a useful survey of the historical and geographical background.

J. G. ELBO

\section{ADMINISTRATION OF HEARD ISLAND AND THE MCDONALD ISLANDS}

[The following statement was issued by the Commonwealth Relations Office on 8 February 1951. An account of the establishment of an Australian meteorological station on Heard Island in 1947 was given in the Polar Record, Vol. 5, Nos. 37/38, 1940, p. 317-23.]

"The Australian Government took over the administration of Heard Island and the McDonald Islands in December 1947, by agreement with the United Kingdom Government. The transfer of the islands was confirmed by an exchange of letters between the two Governments on 19 December 1950. With the agreement of the Australian Government these letters are now published. Heard Island is in lat. $53^{\circ} \mathrm{S}$., long. $75^{\circ} \mathrm{E}$., and the McDonald Islands are in lat. $53^{\circ} \mathrm{S}$., long. $72^{\circ} \mathrm{E} . "$ 